\title{
Ao Professor Marcelo Milano Falcão Vieira
}

\author{
For Professor Marcelo Milano Falcão Vieira
}

Rodrigo Gava ${ }^{1}$

Bill Pereira ${ }^{2}$

\section{Depoimentos}

As palavras que aqui seguem tem como único objetivo homenagear o professor Marcelo Milano Falcão Viera, que há pouco tempo nos deixou a todos, especialmente os seus ex-alunos, cheios de lembranças e saudade. No entanto, a falta que o Marcelo nos faz é amenizada com o imenso aprendizado que nos deixou, não apenas como professor, mas por ser um formador nato, que nos incentivava sempre a dar um passo além. Sendo assim, não é nosso objetivo aqui discutir a contribuição do Marcelo para o campo da Administração, mas deixar registrado dois breves depoimentos nossos em agradecimento a este grande mestre.

O sentimento de choque pela notícia de falecimento do Professor Marcelo Milano logo encontrou afago nos aprendizados obtidos pela oportunidade de tê-lo conhecido. Tive a satisfação de ter sido seu aluno em duas disciplinas no doutorado, de ser orientado por ele e vivenciado seu refinado talento no apoio ao desenvolvimento dos estudos da tese, quando os minutos pareciam horas em aprendizado, e parceiro nos estudos no Observatório da Realidade Organizacional. Lembro-me de sair de seu gabinete na EBAPE com discussões e conclusões que apontavam para um novo capítulo da tese, embora nossas reuniões raramente ultrapassassem 10 minutos. A inevitável, embora precoce, passagem do Professor Marcelo nos reforça a lembrança de a quantos influenciou, de quanto interesse nos despertou para ir ao além do óbvio, o apreço por novas vias para se compreender a realidade organizacional, a crítica constante, o ponto final sempre contextual. Das lembranças desse período de intenso envolvimento com os estudos de doutoramento, serão sempre marcantes e estimulantes a novos desafios as lembranças que, dele, levarei comigo. Marcelo, deixo aqui meu imenso agradecimento.

Rodrigo Gava

Mais do que um amigo pessoal, tive o privilégio de ter também o Marcelo Milano como professor e coorientador durante meu doutorado na EBAPE/FGV. Seus constantes questionamentos e provocações sobre a perspectiva crítica do consumo que eu usava na minha tese chegaram a fazer com que eu escrevesse toda uma seção na minha tese para ele.

Artigo submetido em 09 de fevereiro de 2012 e aceito para publicação em 09 de março de 2012.

${ }^{1}$ Professor Adjunto da UFV. Endereço: Universidade Federal de Viçosa (UFV) - Av. PH Rolfs, s/n, Departamento de Administração e Contabilidade (DAD), Campus Universitário, CEP 36570-000, Viçosa - MG, Brasil. E-mail: rgava@ufv.br

2 Professor do Departamento de Administração e Turismo do Campus de Nova Iguaçu; Universidade Federal Rural do Rio de Janeiro (UFRRJ). Endereço: Av. Governador Roberto Silveira, S/N, CEP 26210-210, Centro - Nova Iguaçu. E-mail: Bill.pereira4@gmail.com 
Mesmo ele sendo um pesquisador da área de Organizações e eu um aluno que enveredava no Marketing, a sua orientação foi fundamental para a minha formação. Como professor, seu constante interesse pelos alunos, seu detalhamento em sala de aula, sua paciência faziam com que nos comprometêssemos mais e mais com nosso trabalho. Como pesquisador, mostrava-nos sempre a importância de se ter uma visão crítica acerca da pesquisa em administração, questionando-nos sempre sobre a importância social de nossa pesquisa. A falta que o Marcelo nos faz só é amenizada pelas lembranças de termos tido o privilégio de ter sido seus alunos.

Bill Pereira 